\title{
フィルム送像設備 (1)
}

\section{1 はしがき}

フィルム送像設備を操作する部屋を一般てフィルム投 写室またはテレシネなどと呼んでいるが，ここでは単に 投写室ということにする.

テレジョン番組は大別して, スタジオ番組, 中継番組 などの生番組とフィルム番組，VTR 再生番組に分けら
ラジオ東京末 次誠

れるが，このうらフィルム番組の時間は普通の映画，文 化映画，これにニュースおよびスポーツなどの報導番組 を含めると相当な割合となり（一例としてラジオ東京に 扣いては，抒よそ30\%程度を占めている)，さらにまた 生番組に数いても番組名, 出演者名, 告知事項, また民 間放送では $\mathrm{CM}$ も殆んぞ投写室送出の映像を使用してい る.このため取扱う機種, 機数も多種にわたっている.

一般に $16 \mathrm{~mm} 35 \mathrm{~mm}$ のフ

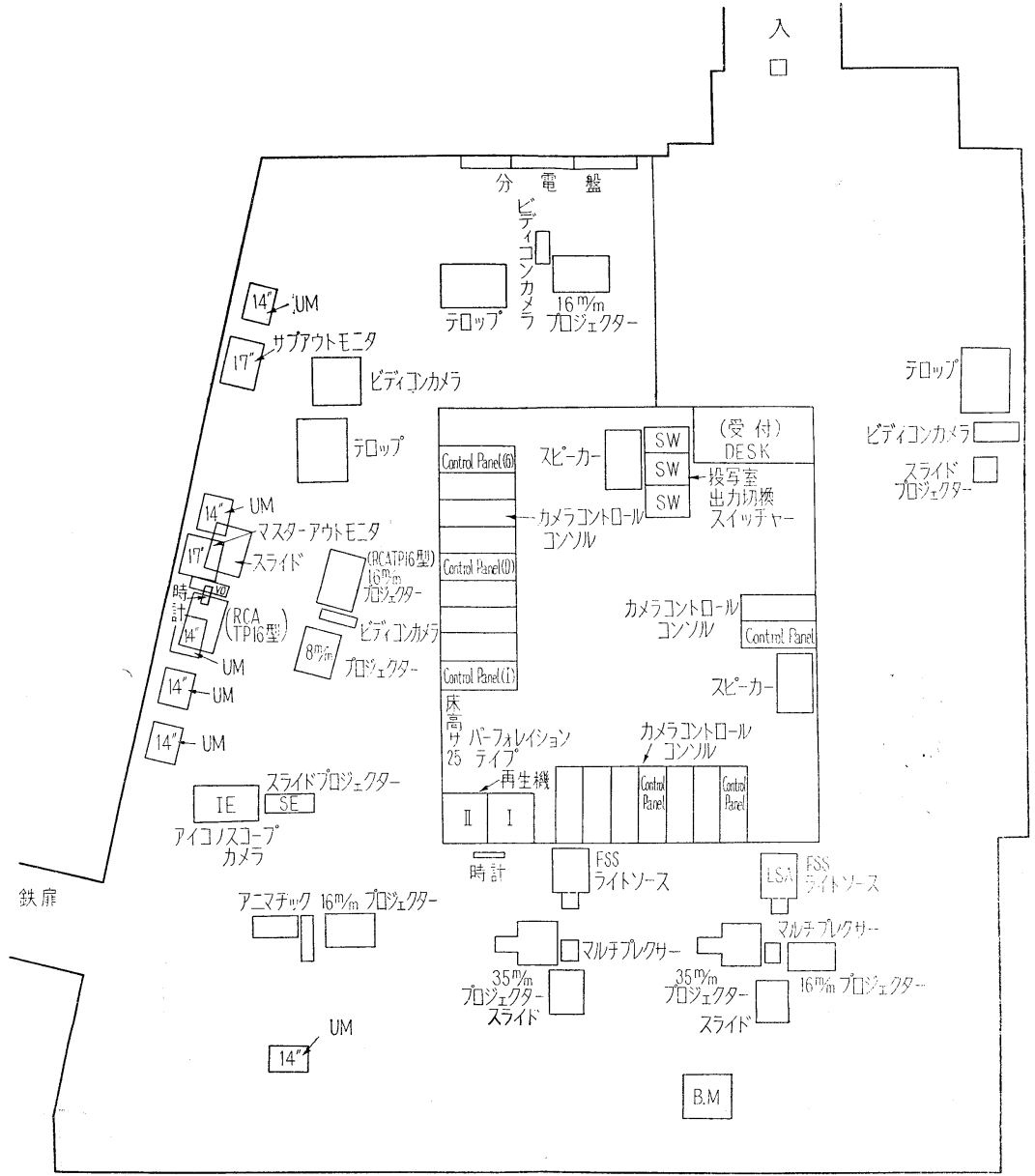

第1図投写室 配 置の一例 イルム，スライド，テロッ プなどの送像設備が操作さ れるが放送局によっては 8 $\mathrm{mm}$ フィルム, 競技得点数 表示器，時刻または経過時 間表示器, アニメーター （相撲等に使用される分解 写真を含む)，スローVTR 送像, パーフォレイション 再生機なども操作されてい る. 以上のように投写室の 設備は相当多種になるが， 中央局で作られる番組を主 として放送し，自社制作番 組の少ない地方の局では， 生番組放送設備は少くても 投写室の機器は一応設備し ているのが普通であり，そ の此重は大きい。

投写室では他の部屋と同 様パルス分配増幅器や安定 化電源，マスターモ二タ類 る使われているが，これら はすでに他の部門で説明せ られているので，ここでは 省略する．また多種の機器 が存在するため概略の説明 となるが，以下送像方法， 
投写室の配置，フィルム映写方式，カメラ拉よびカメコ ン，フライングスポットスキャナー，フィルム映写機， スライド映写機, テロップ装置，スローVTR 再生， パ ーフォレィションテープ再生機, フィルム・スライド・ テロップカードの基準, TV 用フィルムの画質, カラー その他てついて述べる。

\section{2 送像方式}

投写室に和いて映像信号を発生させるためには，カメ ラを使用する方法とフライングスポットスキャナーと光 電管との組合せによる方法とが使われている. 前者は生 番組に使用されるカメラと同様汇撮像カメラを使用して いるが，普通主としてビディコンが使われて括り，これ にアイコノスコープも多少使われている. 後者は高輝度 のブラウン管を正確にスキャニングして出き，この光を スライド执よびテロップの場合は，そのままフィルム面 を透過または反射させてフォトマルティプライャーに入 れて光像を電気信号に変換しているが， $16 \mathrm{~mm}, 35 \mathrm{~mm}$ のフィルムの場合には特殊な光学装置と組合せて映画の 24 コマをテレビの30枚に変換して送出している.

\section{3 投写室の 配 置}

投写室内の配置は機種機数の多少により当然異ってく る. 設備が少い場合にはカメラ系（プロジェクターを含 む)，カメコン系，モ二タ系を並べて配置してもよいが， 種類機数が多くなるとカイラ系はカメコン系と分け，一 番多く使われる $16 \mathrm{~mm}$ 系とテロップ系とを中心とし，二 ュースなどのように飛込みを迅速に処理するようにすれ ば便利である.カメラ系拈よびカメコン系はそれぞれ集 めて配置し，拈のおのの機器は少数の人間が掛持ちでき るようにすれば人員が少くて済む。モニタ系は，マスモ ニはカメコンの所に置き, 各カメラアウトのUMは扮の 沶のカメラの上に置く.さらに室内に $2 \sim 3$ 個の大型の エアモニタを置き（これは切換えて各サブアウトを見る ようにする)，また機数が多く，送出する相手の数が多



第2図スイッチャー附近

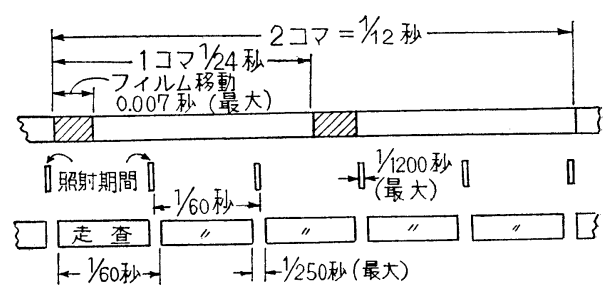

(a)

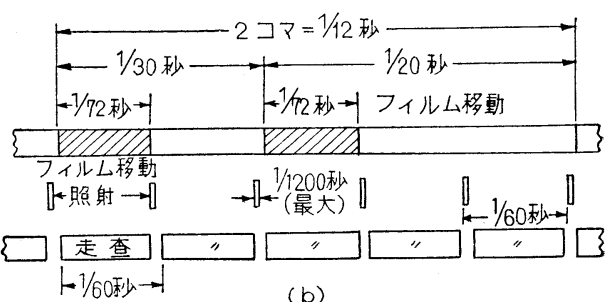

第 3 図（a） 等間隔かき落し方式（b） $2 \sim 3$ かき落し方式

くなれば当然各カメラアウトをスイッチャーで分ける必 要が起り，これを操作する係りは全番組内容と使用する 機器を良く知っておく必要が女るため, 演出側の係りと 容易に打合せできる場所置いた方が便利である、イン ターカムは各スタジオと通話するため数個所各機器の側 に置くが，各スタジオからくる呼出しは一応部屋の中央 のスピーカーで受け，それぞれ担当を予定されている機 器の側にあるインターカムでその担当者が取って話合う ようにすると都合が良い。この場合呼んできた相手はタ リーで表示されて打り，各インターカムのスタジオセレ クトボタンのらち，呼出しを表示しているボタンを押式 ことにより，部屋の中央スピーカーに音声が出ないよう にすると良い、インターカムの配置接続，運用は投写室 操作活動に重大な影響があり，良く考慮する必要がある. 投写室内配置の一例を第 1 図に示す. $16 \mathrm{~mm}$ 系のカメコ ンとテロップ系のカメコンは番組が混雑するとき以外は 一人で兼任できる.

\section{4 フィルム 映写方式}

映画フィルムの毎 秒コマ数は24コマで あり，テレビの毎秒 像数は 30 枚である が，一本飛越走査で あるから実際は60枚 である.この関係を 調整するため普通つ ぎの二方法が採用さ れている.

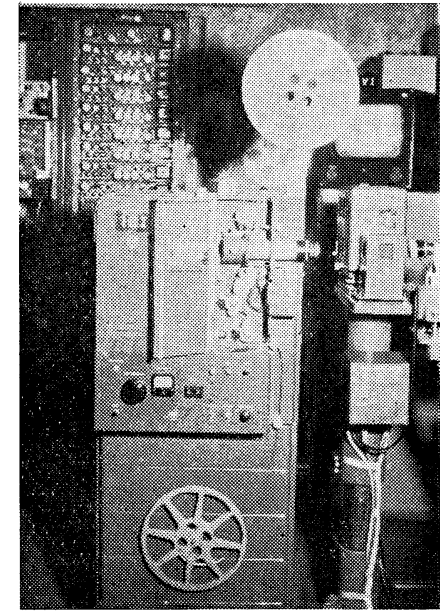

第4図 $16 \mathrm{~mm}$ プロジェクター

$32(180)$ 
（1）間欠式にフィルムを移動静止させ，テレビの60 枚対フィルムの 24 コ、,すなわちフィルムの 4 コマの画 像をテレビの 5 枚の映像に変換する方法

この場合，（a）等間隔かき落し方式，（b） 2-3 かき 落し方式などがめる。

（2）プリズムまたはミラーを使い，機械光学的方法 によりフィルムの各コマがラップしてディゾルブしなが ら静止して結ぶ装置を利用する。普通はこの装置を逆に 働かせ，フライングスポットスキャナーを併用してフィ ルム面を通過して生じた映像電流を得ている。

（1）の間欠方式を第 3 図で説明する。フィルムの 4 コマの画像をテレビの 5 枚の映像に変換することが必要 であるから，フィルムのかき落しが終了し静止している 期間の中垂直ブランキング期間海時間光の照射を行い， 撮像管にフィルム像に応じた電荷を蓄積し, これを走查 して映像信号を取出す方法を採用している.この場合光 の照射は第 3 図(a)のよ5にフィルムの各コマは二回照 射を受けるときと三回のときとが存在するがこのため映 写機のフィルム移動とテレビの同期信号とは同期した一 定の関係を持つようにしている. しかしこの場合フィル ムの移動の直前または直後に照射があるから, 移動の時 間は図のように 0.007 秒という短時間汇行われるばなら ず, $16 \mathrm{~mm}$ に比し質量の大きい $35 \mathrm{~mm}$ フィルムの場合 には不利である. その点第 3 図(b)のよ5に，かき落し の間隔を $1 / 30$ 秒と $1 / 20$ 秒にした $2-3$ かき落し方式ではフ イルムの移動時間を $1 / 72$ 秒にすることが可能でめり，等 間隔方式よりゆるやかである．またこのときかき落し時 間を早くすればその分だけ光の照射時間を長くすること

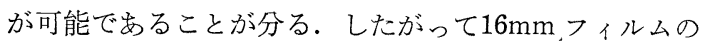
場合にもこの方式を採用すれば，同一かき落し時間なら

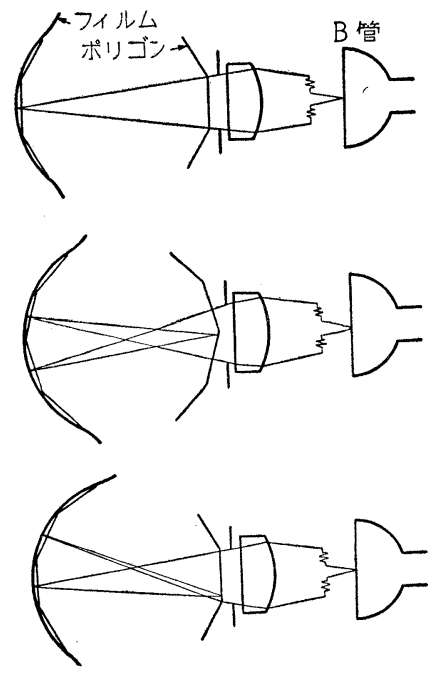

第 5 図 ポリゴンの動作

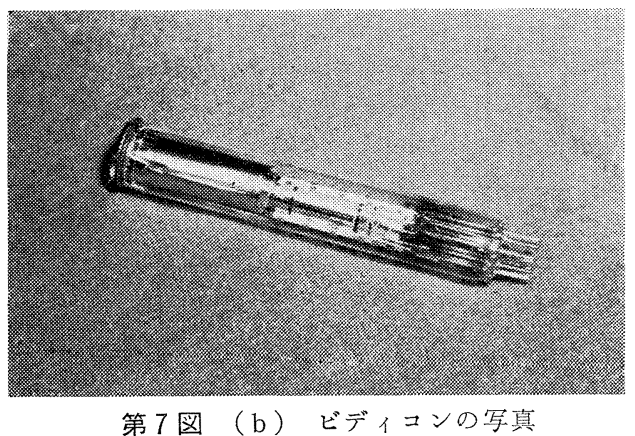

第7図（b） ビディコンの写真

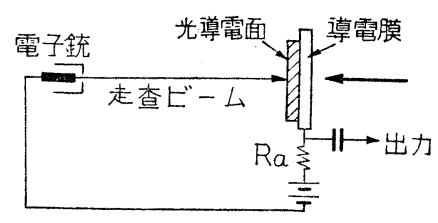

第7図（c） ビディコンの動作

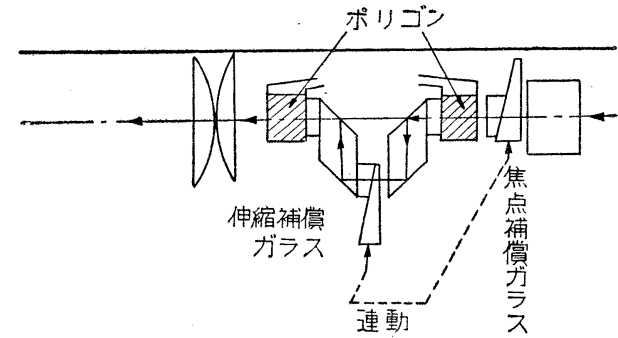

第 6 図フィルム補償光学系

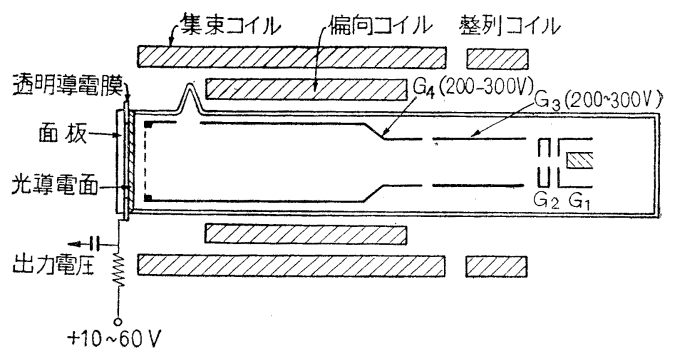

第7図（a）ビディコンの棈造

感度を上げることになり，最近はこの方式が多い，

プリズムまたはミラーを使用する方式は，古くから知 られているメシャウ (Mechau) の映写機と同じく，フ ィルムの各コマが常に静止した位置でディゾルブしなが ら変化して行く方法を逆济利用したもので，プリズムを 使用した米国フィルコ社製の映写機の動作原理を第 5 図 に示す．これは平行ガラス板を通過する光はある限度内 では平行板の角変位に比例して変位するといら光学の原 理を利用しているもので，12枚の平行ガラス板を形成し ている24面のポリゴンがあり，図のような関係で絶党ず フラィングスポットスキャナーよりの輝点がフィルムの 各点をラップディゾルブしながら通過して行くので，そ の透過光をフォトマルティプ ラィヤーに入射させて電気信 号に変換している。この場合 フィルムは連続的に移動して いるから間欠移動方式の上5 にストップ・ランをくり返え さず，したがってフィルムを 痛めることがない。をたフィ ルムの移動速度恃任意で良く フィルムの映写コマ数と同期 信号とは全く無関係であるか ら，中継番組の場合のように 同期信号とフィルム駆動電源 の周期とが同期していないと き泟生番組の画面とフィル 么の画面とをかねることが可 
能である（勿論，闹期信号飞同期し たフィルム駆動電源を作れば上の間 欠式の場合も同様可能であるが). こ の場合もしフィルムに伸縮があると ポリゴンとの相刘的関係が狂い, 画 面のブレやボケの原因となるので, フィルムの伸縮に対してはポリゴン の光学的直径を変化して補償してい る. この関係鸴 6 国江示吉. 光学 径路の長さを変光るには図の伸縮補 償ガラスを上下して左右の菱形プリ ズムとの空吵を変化している．この ときフィルムと映写レンズとの間を

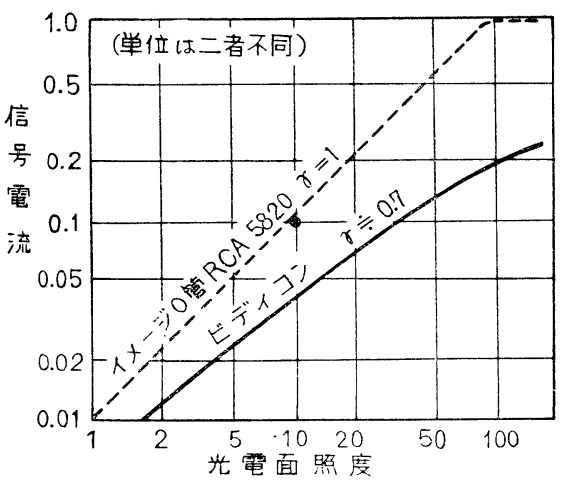

第8図（a）ビディニンの $\gamma$

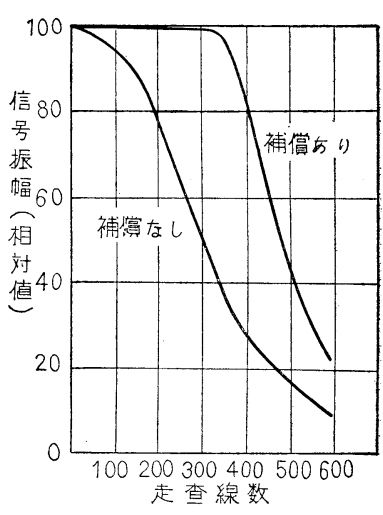

（b）ビディコンの解像力 考光るとガラスと空気との量の割合が変化するため焦点 がボケるので，さらにこれを補償するため図のポリゴ ンの他汇劣る焦点補償ガラスを伸縮補償ガラスと連動し て動かし，その二者の和が常に一定值であるょうにして 補償している。 ポリゴンはその機械的精度がデリケート であるため取扱いに注意する必要があり，プリズムの 位置が少しでも狂うと解像力がただちに低下寸る。

\section{5 カメラおよびカメコン}

投写室で使わ机ているカメラはビディコンカメラが多 い. 生番組と異なり仕事の性格から相当時間, 一つの画 像を静止して送像することが多く, このため焼付の大さ いイメージオルシコンほ使用できない（とくに使用時間 数の多い管では甚だしい). また常にスタンバイの状態 であることが要求されるため寿命も長いことが望まれ， イメージオルシコンの 500〜600 時間に比しビディコン では 1500〜2000 時間と寿命が長く, かつ価格が国産品 之比較して $1 / 2$ 以下であることも有利である. しかし残像

の多い点と感度の低い点は欠点であるが次第㲹改良され てきている，現在一般浪く使われているのは 6326 型 であり，感度はイメージオルシコンの数分の一程度であ るが， $\mathrm{SN}$ 比供相当大学く数 $10 \mathrm{~dB}$ 程度である。 なたア イコノスコープは余り使われていないので省略する。ビ ディコンの構造捛よび動作を第 7 図汅示す.ビディコン もイメージオルシコンと同じく低速度電子ビームを使用 し, 図の整列コイルでビームを軸に合せ，集束コイルで 集束し, 扁向コイルで導電膜を走查する. 入射光がなく て暗い場合光導電膜の抵抗が大きく $\left(10^{12} \Omega-\mathrm{cm}\right.$ 程度 $)$ 信号板に掛けている正電圧 $(+30 \mathrm{~V}$ 程度) は導電膜の走 查側には伝っていない. 光が入るとその量汇比例して電 導度が変り，それを走査ビームが放電して行くのでそれ に比例して $\mathrm{R}_{\mathrm{a}}$ 汇信号電压が出力として生ずる. ビディ コンの特性の一例を第 8 図(a) 江示す. $\gamma$ は約 0.7 程度 である. 第 8 図(b)に 6326 型ビディコンの解像度を示 すが，走查ビームのスポットを十分小さくできないため アパーチュアコレクションによって解像度を上げてい

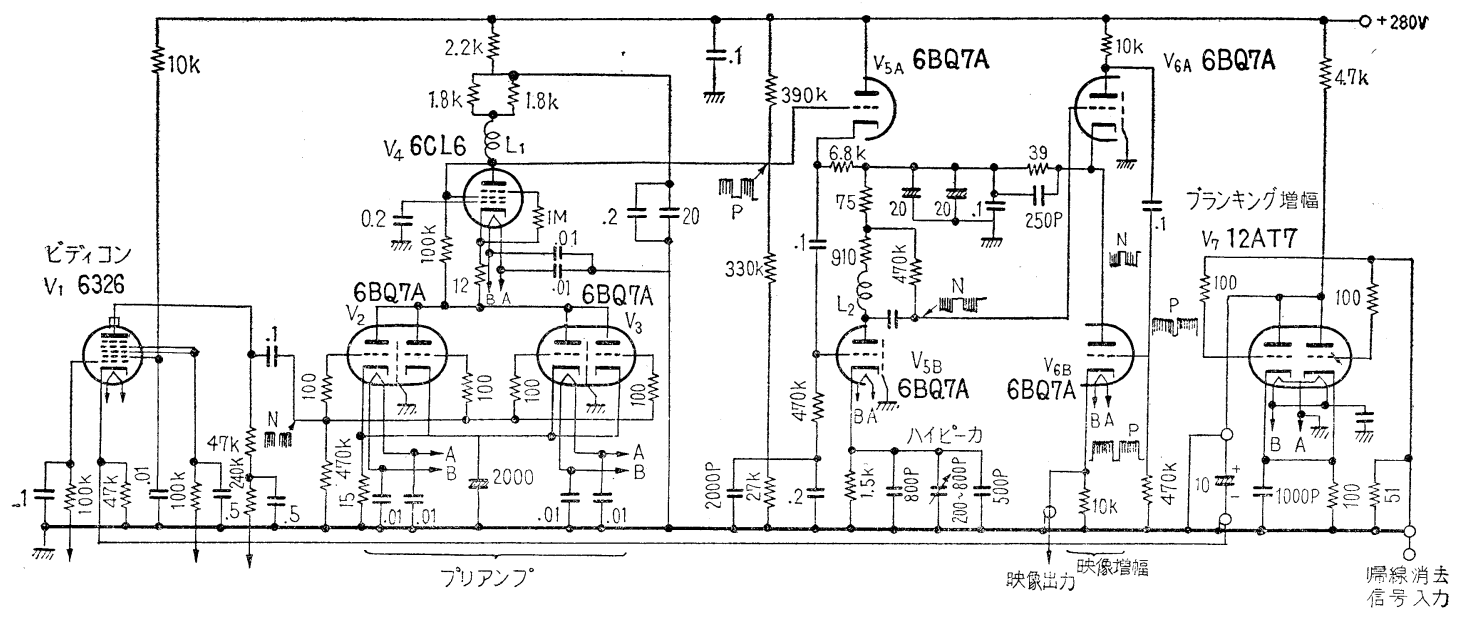

第 9 図ビディコンカメラの映像回路 


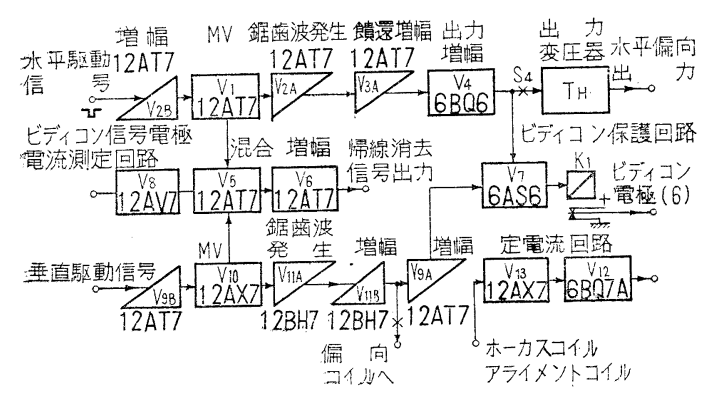

第10図 ビディコンカメラの偏向回路

る. 普通一般に500 本程度迄上げて使用している。

な新ビディコンの画質汇ついては後注述べる。ビディ コンカメラの映像回路の一例を第 9 図汇，之の偏向回路 を簡単にブロックダイヤにして第10図に示す.ビディコ ンでフィルム范送像する際は, つぎのような操作を行 う。すなわ台フィルムの蕽度筫囲はテレビ系で再生可能 なコントラストレインジょり遥るかに大きく, 灌度でい 完ば 0.1〜3.0すなから約 1000 倍程度で岁り, テレビ のそれは 0.4〜1.9すなわら約30倍程度である。このた めとくにテレビ用として製作したフィルム以外のフィル ムを艺のまま再生すれば，黑はつぶれ，白は飛んでいる ことになる．これを避けるためビディコンの入力光を画 面の変化と共飞制限することが望ましい，これができな いときには，カメラの出力電圧を常濫視したがら加減 してやる必要がある。李たこのとき同時汇べデスタルる 常汇調節することが必要である.

\section{6 フライングスポットスキャナー}

フライングスポットスキャナーは前述ベた連続式つ タルムプロジェクターと組合せて使用されることが多い が，勿論，スライドをなはテロップにも使用されてい

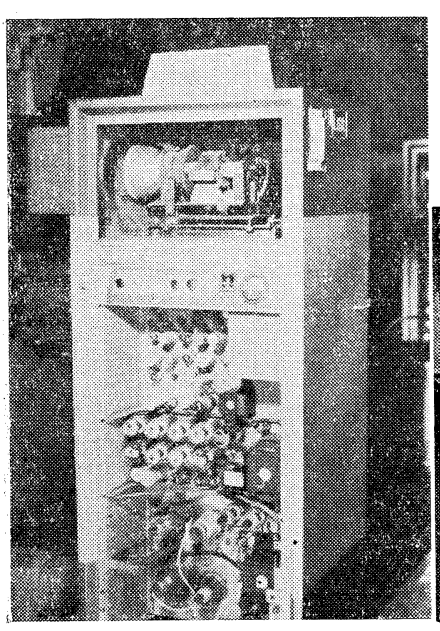

第 11 図
る. 高輝度の残像性 の少ないスポットの 鋭いブラウン管を正 確に偏向して発光さ

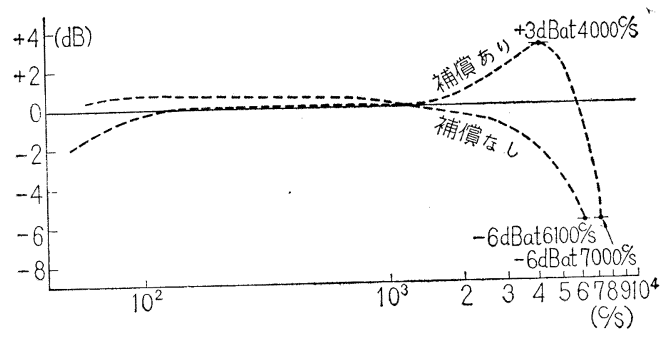

第12図フィルム映写機の再生率の一例 まま画面を透過または反射させ，それを光電変換させて 映像電流とする.フィルムの場合は前述のポリゴンと併 用する。この方式はシェーディングが発生せず解像力が 良く（とくにスライドで良い）画面のリニアリティーを 正確に調整して，テストパターンをして使用されること が多い．また一個のライトソースからフィルム系にも， スライド系汅も分けて使用することは便利である（光電 変換部分はビディコンカメラに比し簡単である).

さらにまたカラー・テレビの場合も, 三色分解後のレ ジストレィションは機械光学的注わなければ正確であ り,フィルムの場合ポリゴン部分の光学系の光のロスを 減らすよう亿努力すれば, レジストレイションの点では 赤, 青, 緑別々の撮像管を使用する方式の困難さ比し 甚だしく有利である。またシェイデイングのない点もカ ラーの場合非常に有利である. 使用ブラウン管としては 5 AKP-24 が主として使われ，フォトマルティプラィヤ 一としてはRCA6292 型が良く使われている. B管の八 イテンとしては $25 \sim 35 \mathrm{kV}, 200 \mu \mathrm{A}$ 程度である. この放 射線が多少発生しているが電圧が低いため, 䩒質の X線 であり, 強さも大したことはないため長時間 B管の附近 に体を露さない限り害は少ない。当社で測定した一例と してはB管正面 $1 \mathrm{~m}$ の地点で每分 1 万カウント程度であ った。ハイテンには手を絶体湾触れてはならないが，吸 引されたゴミ壳掃除する際も, ハイテン回路をアースし て执く必要がある。この方式で $\mathrm{B}$ 管よりの光線の強さが 弱いと, そのコントラスト簯团が小さくなり, 黒, 白と

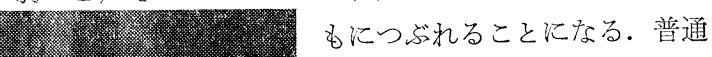

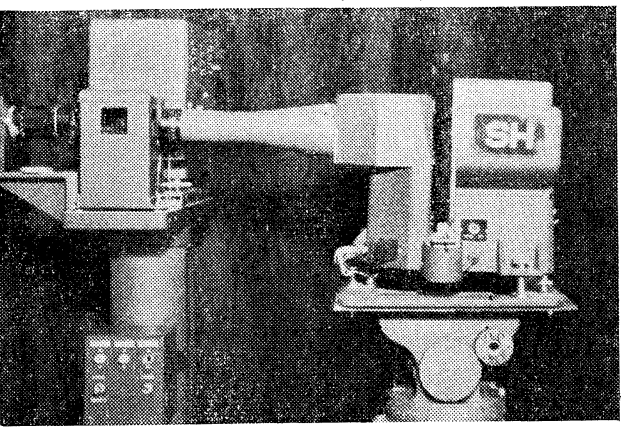

第13図 スライド映写機 の映画用フィルムに使用する際 は，ガンマコレクターを併用し ている.これの画質関しては また後に述べる。

\section{7 フィルム映写機}

フィルム映写機としては前に述 だた間欠移動式と連続移動式があ るが間欠式の場合，等間隔かき落 
し方式より 2-3かき落し方式の方がシャッ ター開角度を大きく取ることができるため， 光源ランプを暗くすることがでさる，ある $16 \mathrm{~mm}$ 映写機で比較使用した結果, 前者で 750Wの電球を使用するのに後者では $300 \mathrm{~W}$ で同等に使用できた。また電球の寿命は 13 時間程度であるが電圧を落して使用すれば 長くなるか，末たは危険度を減少すること ができる．音声の再生は普通の映写機と同 様でめり, エクサイター光源として $30 \mathrm{kc}$ 程度の高周波電流でランプを点火している。 その周波数特性の一例を第11図汇示す．最 近 $16 \mathrm{~mm}$ フィルムのパーフォレイションの 無い側化磁気コーティングを施して録音す ることが行われている. この場合, 周波数 特性, ひず反率, ダイナミックレインジと もに光学的録音より良い. $16 \mathrm{~mm}$ フィルム

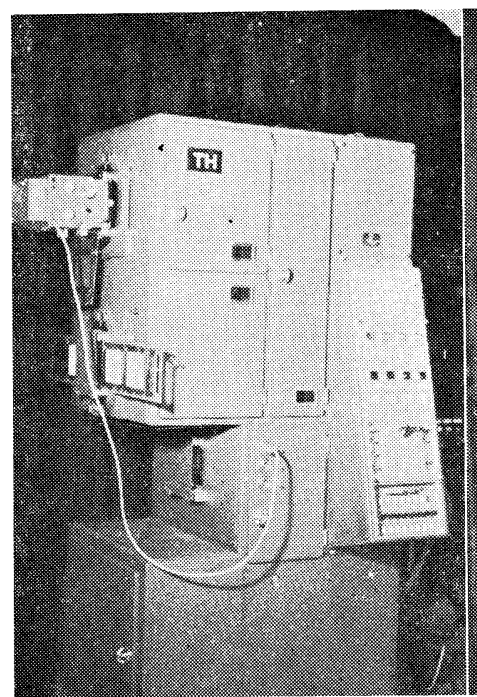

第14図テロップ装置

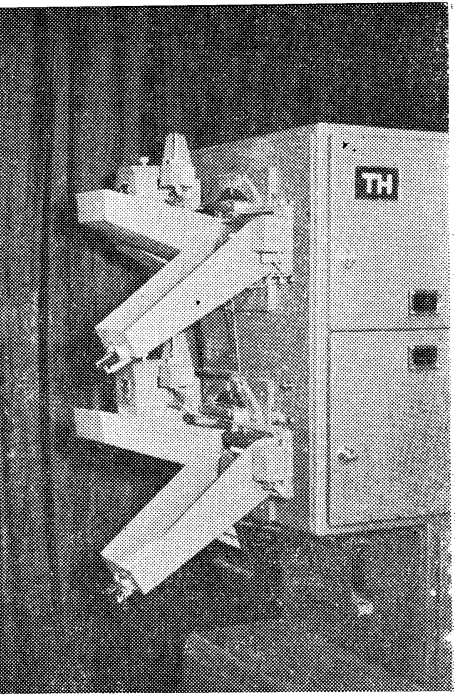

第 15 図カード自動送出装置 は厚さが普通磁気録音テープより厚く, かつ弾性も強い ため再生へッドとの接着が悪く, そのため録音テープほ ぞの良い特性は得られない。既設の $16 \mathrm{~mm}$ 映写機は改造 しなければ磁気録音フィルムは使用できず，ハムの混入 その他の問題もあり，まだ余り普及していない現状であ る.

\section{8 スライド映写機}

スライド映写機は，第13図のような型の物が多く使わ れている. これはビディコンカメラと組合せ使用せられ るため, 光源として $150 \mathrm{~W}$ 程度の電球を使用している。 フライングスポットを組合わせるときは，フォトマルテ イプライヤーが代りに入っている. 一枚の円盤に 8 枚程 度入れているから一度に16枚送られる. 画面寸法として は $23 \times 32 \mathrm{~mm}$ 程度であるが，あとに詳しく述べることと する。

\section{9 テロップ装 置}

テロップといら名称はアメリカの GRAY 社の商品名 であるが，わが国では反射光による投写装置のことをす ベて呼称している. テロップはカード以外にもロール状 の長い紙も投写され, さらに競技の得点表示器や時刻の 表示器も装着することができる.わが国で使われている ものは第14図に示す方式のものが多く, この場合投写空 口は上下二つあり, 二つの空の画像を光源ランプの点滅 で切換えている.テッップカードは普通カードホルダー に $5 \sim 7$ 枚組末れて順次手動で送られている. 連続して 送られるカードの数が 10 枚以上にもなると, カードホル ダーを一枍づつ送り, ランプを点隇する操作以外にホル ダーの差換えをも行わ视ばならず，一人では不可能とな

ってくる.人員節約のためこのカードの送りを能動的に する装置が最近種々作られている. 第15図はとの一例で ある、またロール㲹書かれた画像を画面の縦をたは横の 方向に移動させるロール巻取器やカードの画面を回転さ せる器具, 画面を暖廉のような模様で変える器具や, 光 学的ワイプやフォーカスアウトで変える機構などが種々 附属している.

使用電球は一枚のカードに $500 \mathrm{~W}$ 電球を電圧を下げて 二個使用している.カード寸法, 画面寸法は大略 $4 \times 5$, 时, $3 \times 4$ 时である.

（次号に続く）

\section{[参 考 文 献]}

（1）イメージオルシコンの寿命試験結果：中山，西山，宫代，小田川 昭和 34 年電気通信学会全国大会予稿 p. 274

（2）イメージオルシコンのターグット持よびマルチプライヤの利得の測 定法：恒岡, 小田川 昭和 31 年電気通信学会全国大会予稿 p. 129

（3）イメージオルシコンのビーム変調度：宮地, 二宮, 海老沢 昭和 30 , 年電律通信学会秋季大会予稿 p. 123

(4) "Am Improved dc Amplifier for Portable Ionization Chamber Instruments', , N.F.Moody Rev, Sci, Inst, 22: $\begin{array}{lll}\text { April } 1951 & \text { p. } 236\end{array}$

（5）イメージオルシコンの燒付現象に関する研究 (第一報)，二宫，海 老沢 昭和 31 年電気通信学会全国大会予稿 p. 122

(6) テレビジョンスタジオ技術の諸閭題： 林寒 テレビジョン簤13巻 9 号 p. 386

（7）イメージオルシコンに拈けるビームランジング：小因川 電気通 信学会誌 $41, \quad$ （昭和 33 年） 9 p. 850

（8）低速度電子走査機構に関する考察：宮代 電気通信学会誌 41 ，（昭: 和 33 年) 12, p. 1226 